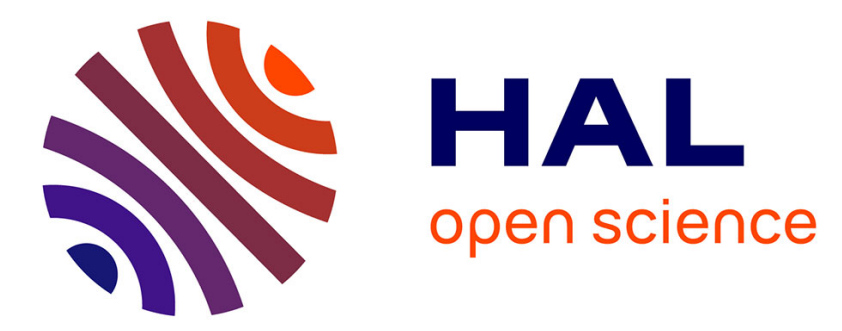

\title{
Wnt $/ \beta$-catenin pathway and cell adhesion deregulation in CSDE1-related intellectual disability and autism spectrum disorders
}

E. El Khouri, J. Ghoumid, Damien Haye, Fabienne Giuliano, L. Drevillon, A. Briand-Suleau, P. de La Grange, V. Nau, T. Gaillon, T. Bienvenu, et al.

\section{- To cite this version:}

E. El Khouri, J. Ghoumid, Damien Haye, Fabienne Giuliano, L. Drevillon, et al.. Wnt/ $\beta$-catenin pathway and cell adhesion deregulation in CSDE1-related intellectual disability and autism spectrum disorders. Molecular Psychiatry, 2021, 10.1038/s41380-021-01072-7 . hal-03208858

\section{HAL Id: hal-03208858 https://hal.science/hal-03208858}

Submitted on 26 Apr 2021

HAL is a multi-disciplinary open access archive for the deposit and dissemination of scientific research documents, whether they are published or not. The documents may come from teaching and research institutions in France or abroad, or from public or private research centers.
L'archive ouverte pluridisciplinaire HAL, est destinée au dépôt et à la diffusion de documents scientifiques de niveau recherche, publiés ou non, émanant des établissements d'enseignement et de recherche français ou étrangers, des laboratoires publics ou privés. 


\section{TITLE PAGE}

Wnt/ $\beta$-catenin pathway and cell adhesion deregulation in CSDE1-related intellectual disability and autism spectrum disorders

Elma EL KHOURI PhD ${ }^{1}$, Jamal GHOUMID MD-PhD ${ }^{2,3}$, Damien HAYE MD ${ }^{4}$, Fabienne GIULIANO MD ${ }^{4}$, Loïc DREVILLON PhD ${ }^{2, \$}$, Audrey BRIAND-SULEAU PhD ${ }^{2,5}$, Pierre DE LA GRANGE PhD ${ }^{6}$, Valérie NAU $\mathrm{BSC}^{1}$, Thierry GAILLON BSc ${ }^{2}$, Thierry BIENVENU PharmD-PhD ${ }^{5}$, Hélène JACQUEMIN-SABLON PhD ${ }^{7}$, Michel GOOSSENS MD-PhD ${ }^{2}$, Serge AMSELEM MD-PhD ${ }^{1}$, Irina GIURGEA MD-PhD ${ }^{1,2^{*}}$

1. Sorbonne Université, INSERM, Maladies génétiques d'expression pédiatrique, Département de Génétique médicale, Assistance Publique Hôpitaux de Paris, Hôpital Trousseau, Paris, France

2. Département de Génétique, Groupe Hospitalier Henri Mondor, Créteil, France

3. Service de Génétique clinique, Hôpital Jeanne de Flandre, CHU Lille, Lille, France

4. Service de génétique médicale, Centre hospitalo-universitaire de Nice, Nice, France

5. Service de Génétique et Biologie moléculaires, Hôpital Cochin, INSERM UMR1266 - Institute of Psychiatry and Neuroscience of Paris (IPNP) and university of Paris, Paris, France

6. GenoSplice, Paris, France

7. INSERM UMR1053 Bordeaux Research in Translational Oncology, BaRITOn, Bordeaux, France

${ }^{\S}$ current affiliation: CHU Caen Normandie, Caen, France

*corresponding author

\section{Corresponding author information:}

Irina Giurgea

Unité mixte de recherche UMR_S933 - Maladies génétiques d'expression pédiatrique Hôpital Armand Trousseau 26, avenue du Docteur Netter Paris 75571 Cedex 12, France Tel: +33 (0)1 447352 45, Fax: (33) 144735219 Email: irina.giurgea@inserm.fr

Running title: CSDE1-related intellectual disability and autism 


\section{ABSTRACT}

Among the genetic factors playing a key role in the etiology of intellectual disabilities (ID) and autism spectrum disorders (ASD), several encode RNA binding proteins (RBPs). In this study, we deciphered the molecular and cellular bases of ID-ASD in a patient followed from birth to the age of 21, in whom we identified a de novo CSDE1 (Cold Shock Domain-containing E1) nonsense variation. CSDE1 encodes an RBP that regulates multiple cellular pathways by monitoring the translation and abundance of target transcripts. Analyses performed on the patient's primary fibroblasts showed that the identified CSDE1 variation leads to haploinsufficiency. We identified through RNA-seq assays the $\mathrm{Wnt} / \beta$-catenin signaling and cellular adhesion as two major deregulated pathways. These results were further confirmed by functional studies involving Wnt-specific luciferase and substrate adhesion assays. Additional data support a disease model involving APC Down-Regulated-1 (APCDD1) and cadherin-2 ( $\mathrm{CDH} 2)$, two components of the $\mathrm{Wnt} / \beta$-catenin pathway, $\mathrm{CDH} 2$ being also pivotal for cellular adhesion. Our study, which relies on both the deep phenotyping and long-term follow-up of a patient with CSDE1 haploinsufficiency and on ex-vivo studies, sheds new light on the CSDE1dependent deregulated pathways in ID-ASD. 


\section{INTRODUCTION}

Intellectual disability (ID) is a neurodevelopmental condition characterized by significantly impaired intellectual functioning affecting the ability to learn, reasoning and problem solving and by deficits in adaptive behavior, hindering day-to-day social and practical skills (1). ID is usually associated with other co-occurring neurodevelopmental disorders and a large majority of patients with ID also present with features of autism spectrum disorders (ASD). The co-occurrence of these two disease conditions is accounted for by their common molecular and genetic origin as several genes have been shown to be involved in both ID and ASD $(1,2)$. Many of the identified mutations are responsible for dysfunctions of specific key signaling pathways, such as the TGF- $\beta /$ BMP (Transforming growth factor-beta/bone morphogenetic protein), the $\mathrm{Wnt} / \beta$-catenin, the SHH (Sonic Hedgehog), and the retinoic acid signaling pathways (reviewed in (3)). For instance, ID-ASD-causing mutations have been reported in genes encoding proteins involved in several steps of the Wnt/ $\beta$ catenin pathway, like the upstream ligands WNT1 and WNT2 (4-7), the downstream transcription factor TCF7L2 $(8,9)$ or the $\beta$-catenin (CTNNB1), the core element of this pathway (10-13). Other major players involved in the onset of ID-ASD are RNA-metabolism regulators and RNA-binding proteins (RBP). This is for instance the case for the FMR1 gene responsible for the Fragile $\mathrm{X}$ syndrome (FXS), the most common heritable form of ID-ASD (14), but also several other genes involved in IDASD (e.g. UPF3A and B, SMG6, EIF4A3, RNPS1, PQBP1, and VCX-A) (15-19). However, despite these advances in identifying ID-ASD-causing mutations, the molecular diagnosis of these conditions is challenging owing to the high clinical and genetic heterogeneity. Furthermore, whole genome sequencing or whole exome sequencing approaches are constrained by the identification of huge amount of variants in each patient and by the large number of patients that have to be studied considering the ID-ASD prevalence ( 1 to $3 \%$ of the general population) (20-22). It is therefore crucial to conduct molecular studies relying on a precise phenotype that could be associated with mutations in a given gene or set of genes.

Here, we describe the case of a patient followed from birth to the age of 21, presenting with severe ID and features resembling the Pitt-Hopkins syndrome (PTHS, MIM \#610954) a neurodevelopmental disorder characterized by recognizable facial features and behavioral abnormalities, among which some overlap with ID-ASD. The patient carries no pathogenic variation in TCF4 (Transcription factor 4, MIM\#602272), the gene involved in PTHS $(23,24)$, a result that led us to perform an in trio exome sequencing in the patient and his healthy parents. This analysis identified a de novo heterozygous nonsense variation in CSDE1 (Cold Shock Domain-containing E1 - also known as UNR: Upstream of NRAS, MIM \#191510) in the patient. CSDE1, a ubiquitously expressed RBP with high affinity for 
mRNAs containing A/G-rich binding motifs $(25,26)$, binds to regulatory regions of its targets transcripts, i.e. the 5'UTR and 3'UTR (untranslated regions) or the IRESs (Internal Ribosomal Entry Sites) to control their translation (26-29) and abundance $(25,30,31)$. CSDE1 is involved in a multitude of biological processes, namely cell cycle and migration, apoptosis as well as embryonic development, neurogenesis and neuronal differentiation (27-32). The diverse CSDE1 targets and their associated biological processes could account for its involvement in the occurrence of multiple disease conditions (reviewed in (33)) as diverse as cancers, Diamond-Blackfan anemia or ASD. CSDE1 is one of the genes mentioned in ASD large scale studies (34,35), and has recently been reported in patients with neurodevelopmental disabilities (36). However, the CSDE1-related pathways involved in the pathophysiology of ID-ASD have not been explored in patient-derived cells so far.

The identification of a nonsense CDSE1 mutation in our patient, whose disease phenotype has been accurately described over two decades, prompted us to perform diverse functional ex-vivo studies with the aim to decipher the CSDE1-dependent biological pathways involved in the pathophysiology of ID-ASD. 


\section{MATERIALS AND METHODS}

The affected patient and the healthy individuals - Informed consents were obtained from patient's parents and from the healthy individuals participating in the study for genetic tests, skin biopsies, data sharing and publication of the patient's photographs according to French legislation and the principles of the Declaration of Helsinki.

Whole exome sequencing - Genomic DNA was extracted from a peripheral blood sample and captured with the SureSelect HumanAll Exon V2 kit (Agilent, Santa Clara, CA). Whole-exome sequencing was performed (Integragen SA, Evry France) on a HiSeq 2000 (Illumina, San Diego, CA) according to the manufacturer's recommendations. Alignment was carried out as previously described (37).

Sanger sequencing and semi-quantitative PCR - for the TCF4 and CSDE1 genes were performed as previously reported (38).

Fibroblasts' culture - Skin biopsies were performed in the patient at the age of 14 and in five healthy donors aged between 10 and 33 years (three adults and two children - males and females). Fibroblast cultures were handled as previously described (39) and used for RNA-seq analysis and for functional studies.

RNA extraction and quantitative RT-PCR assay - Total RNA from fibroblasts was isolated using RNAeasy Mini Kit (Qiagen, Germany) and $1 \mu \mathrm{g}$ of RNA was subjected to reverse transcription using Reverse Transcriptor kit (Roche, Switzerland) according to the manufacturers' instructions. cDNA was amplified using the Mesa Blue qPCR MasterMix Plus (Eurogentec, Belgium) in the Light Cycler LC480 (Roche). Primers are provided in Supplementary Information.

RNA-seq - Total RNA was captured using TruSeq Stranded Total RNA with Ribo-Zero Gold (Illumina, San Diego, CA) sequencing was performed (Integragen SA, Evry France) on a HiSeq4000 (Illumina, San Diego, CA) according to the manufacturer's recommendations. RNA-Seq data analysis was performed by GenoSplice (www.genosplice.com). Sequencing, data quality, reads repartition, and insert size estimation were performed using FastQC, Picard-Tools, Samtools and rseqc. Reads were mapped using STARv2.4.0 (40) on the hg19 Human genome assembly. Gene expression regulation study was performed as previously described (41). Further information is provided in Supplementary Information. Pathway and process enrichment analysis was performed by Metascape (42) as 
described in Supplementary Information. Data from three healthy individuals were compared to those obtained from the ID-ASD patient.

Nonsense-mediated mRNA decay assessment - Fibroblasts were treated with $30 \mu \mathrm{g} / \mathrm{mL}$ cycloheximide (Sigma Aldrich, MO, USA) or DMSO for $4 \mathrm{~h}$. Total RNA was extracted and subjected to reverse transcription. PCR amplification was carried out using the Q5 (New England Biolabs, MA, USA) PCR products were purified using ExoSap (Thermo Fisher Scientific, MA, USA) before being sequenced.

Western blot analysis - Protein expression analyses in fibroblasts were performed using a standard Western blot protocol and specific antibodies as described in Supplementary Information. Proteins were detected with Amersham ECL Select Western Blotting Detection Reagent (GE healthcare, III, USA) according to the manufacturer's recommendations and BioRad ChemiDoc Imaging Systems (BioRad, CA, USA) was used for detection. The ImageJ software was used for signal quantification.

Luciferase assay - Fibroblasts were transiently transfected with $2 \mu \mathrm{g}$ of the $\beta$-catenin-responsive firefly luciferase reporter plasmid TOPFlash (Millipore, Ma, USA) or the negative control FOPFlash (Millipore) by a double transfection using Lipofectamine LTX (Thermo Fisher Scientific) and Fugene (Promega, Wis, USA) at equal amounts according to the manufacturer's instructions. 24 hours after transfection, cells were treated with $20 \mathrm{mM} \mathrm{LiCl}$ for 6 hours then lysed with Passive Lysis Buffer (Promega). Samples were incubated for $30 \mathrm{~min}$ at $4^{\circ} \mathrm{C}$ and then centrifuged for $1 \mathrm{~min}$ at 13000 g at $4^{\circ} \mathrm{C}$. Supernatants were collected and firefly luciferase activity was measured according to the manufacturer's instructions. The firefly luciferase activity was normalized against protein amounts and relative TOPFlash/FOPFlash activity was reported.

Adhesion assay - Fibroblasts were deprived of serum for 8 hours and then detached using $10 \mathrm{mM}$ EDTA in DMEM for 10 min, washed twice with DMEM (Thermo Fisher Scientific) and resuspended in $2 \mathrm{~mL}$ of DMEM with $0.1 \%$ BSA. $100 \mu \mathrm{L}$ of cell suspension was added by well of a 96-well plate precoated for 12 hours with $40 \mu \mathrm{g} / \mathrm{mL}$ Collagen I (Corning, NY, USA) in PBS. The plate was incubated $20 \mathrm{~min}$ at $37^{\circ} \mathrm{C}$ to allow cell adhesion. Cells were then washed and cultured for 4 hours in DMEM supplemented with 10\% FBS to enable recovery. Cells were then counted using MTT cell proliferation assay kit (ATCC, VA, USA).

Statistical analyses - Statistical analyses and graph representation were performed using GraphPad Prism 5.0 software (GraphPad Software Inc.). Unpaired two-tailed Student's t tests were used for 
comparisons of means of two groups. The means of data provided by sets of independent experiments carried out on samples from the patient were compared to the means of data provided by sets of independent experiments carried out on samples from three healthy individuals. Data are presented as means \pm SEM and individual data points are represented when scatter plots are used. 


\section{RESULTS}

\section{Case history and patient's phenotype}

The medical history of the patient (individual II.1 in Figure 1A \& 1B) from birth to the age of 21 is the following: the patient was born to non-consanguineous healthy parents; increased fetal nuchal skinfold thickness was observed during the 2 nd trimester of pregnancy. Birth was uneventful and birth measurements were normal. He presents no malformation or Hirschsprung disease. He was first referred for genetic counseling at the age of 5 years for hypotonia and developmental delay. The diagnosis of Pitt-Hopkins syndrome was suspected at the age of 10 based on facial features, smiling appearance, ataxic gait, and repetitive behavior, associated with severe ID and absence of speech. Motor milestones were delayed as he walked at the age of 8 . He also experiences generalized tonicclonic seizures with a frequency of one seizure every 2 months. Facial features comprise long thin eyebrows, long eyelashes, narrow palpebral fissures, epicanthic folds, divergent squint, a short nose with broad nasal bridge, macrostomia with thick lips and small spaced teeth. He also presents pectus excavatum, genu flexum, amyotrophy, flat feet, a brachydactyly of the third toe and mild camptodactyly (Figure 1A and Table 1). Brain MRI and muscle biopsy showed no abnormalities. Other features include scoliosis, lymphomatoid papulosis, testicular ectopia and recurrent alternation of constipation/diarrhea (Table 1). At the age of 21, the patient is $1 \mathrm{~m} 69$ tall, he weighs $47 \mathrm{~kg}$ and has a head circumference of $60.5 \mathrm{~cm}$ (within the normal range). He still lacks speech capacities and exhibits a friendly behavior with no signs of aggressivity. He eats alone but cannot dress himself and is not toilet trained. He has sleep disturbance.

\section{Identification of a CSDE1 c.362C>A p.(Ser121*) heterozygous de novo variation in the patient with severe ID}

As no molecular abnormalities were found in TCF4, the gene involved in the Pitt-Hopkins syndrome, whole-exome sequencing was performed and identified the de novo heterozygous nonsense variation c.362C>A, p.(Ser121*) in CSDE1 (NM_001242891). The identified variation has not been described in sequence-variant databases, such as the genome aggregation database (gnomAD). Sanger sequencing confirmed that the $c .362 C>A$ variation is carried by the patient and absent in his parents (Figure 1B). Another de novo missense variation c.616C>T, p.(Leu206Phe) was identified in the GNB2L1 gene (NM_006098). Taking into account the previously reported involvement of CSDE1 in ID-ASD (36) and the nature of the identified variation (nonsense), we sought to further study the functional impact of this gene variation. As the identified variation leads to a premature termination codon (PTC) in the $4^{\text {th }}$ exon of CSDE1, which contains 21 exons, it is expected to result either in the production of a truncated protein or in the absence of protein production through activation of the 
nonsense-mediated mRNA decay (NMD) pathway. Indeed, mutant PTC-containing mRNAs are expected to be degraded through the NMD signaling pathway, unless the PTC is located more than 50-55 nucleotides upstream of the last exon-exon junction $(43,44)$. To discriminate between these two possibilities, we sequenced the CSDE1 transcripts obtained from the patient's fibroblasts before and after treatment with cycloheximide, an inhibitor of the NMD pathway. The patient's fibroblasts expressed only the normal CSDE1 allele, whereas cycloheximide led to accumulation of the mutated CSDE1 transcripts (Figure 1C). These data indicate that NMD plays an active role in the degradation of the mutated CSDE1 transcripts that contain a premature stop codon. Consistent with this observation, we found a $50 \%$ decrease of CSDE1 transcripts from total RNA extracted from the patient's skin fibroblasts as compared to healthy individuals (Figure 1D), leading to a $\sim 40 \%$ decrease in CSDE1 protein levels (Figure 1E). Taken together, these data demonstrate the deleterious character of the identified c.362C>A variation, which leads to CSDE1 haploinsufficiency.

\section{Recurrent phenotypic features in patients upon partial loss of CSDE1}

With the aim to identify the main phenotypic features associated with a partial loss of CSDE1, we analyzed the phenotype of our patient and compared it to the phenotypes of the previously reported individuals carrying a deletion encompassing CSDE1 (located on the short arm of chromosome 1, 1p13.2) $(45,46)$ and the recently reported ASD patients carrying truncating CSDE1 mutations (36). All phenotypic features are summarized in Table 1. Noticeably, the patients share some common features among which the most recurrent clinical symptoms are language impairment (20/20), motor developmental delays (18/20), intellectual disabilities (17/19), and autistic features (12/16).

\section{Deregulation of major cellular pathways upon partial loss of CSDE1 in the patient's fibroblasts}

CSDE1 interacts with a large number of transcripts to regulate multiple cellular pathways. In order to identify the pathways hindered upon partial loss of CSDE1 in the patient, we performed an RNA-Seq transcriptomic analysis on fibroblasts obtained from the patient and three healthy individuals. This analysis showed that the steady-state of 1,131 transcripts is significantly modified in the patient's fibroblasts compared to the healthy individuals (545 upregulated genes and 586 down-regulated genes), with a cut-off of 0.05 for the unadjusted $p$-value and a minimum fold change of 1.5 (Table S1 - Data deposited at Gene Expression Omnibus GEO, Accession code GSE162954). Gene ontology (GO) biological process term analysis was performed to identify the key pathways related to the differentially expressed genes using Metascape (http://metascape.org, (42)). The statistically enriched terms identified were hierarchically clustered into a tree based on the similarities among their gene memberships. The GO enrichment analysis revealed that the most significantly upregulated genes were associated with the regulation of the cell cycle and cell division (e.g. CDC25A, 
CDC20, CHEK1, E2F1) (Figure 2A - left panel and Table S1). Noteworthy, the down-regulated genes were essentially involved in the homophilic cell adhesion via plasma membrane adhesion molecules, mainly belonging to the cadherin and protocadherins family e.g. $C D H 4, C D H 6, C D H 10, P C D H 7$, PCDHA9, PCDHB5 (Figure 2A - right panel and Table S1).

In order to further characterize the specific contribution of the CSDE1 loss-of-function mutation in these transcriptomic data, we focused our analyses on genes containing CSDE1 binding motifs. To this end, we conducted a comparative study of our results with those obtained by Ju Lee et al. in their transcriptomic analysis of genes containing at least one consensus CSDE1 binding motif upon CSDE1 knockdown in human embryonic stem cells (31). Furthermore, the identification of deregulated genes common to fibroblasts and embryonic stem cells allowed us to palliate the bias linked to a cell-type specific analysis. The comparison of the list of deregulated genes detected in our study with the list of Ju Lee et al. (531 up-regulated genes and 676 down-regulated genes retained on the basis of a log2-fold change and at a False Discovery Rate (FDR) $<0.05)$ identified 30 and 33 common genes that are up- and down-regulated, respectively (Figure $2 \mathrm{~B} \& 2 \mathrm{C}$, top panel). We conducted GO enrichment analyses on these genes and all statistically enriched terms were converted into a network layout (Figure 2B \& 2C, bottom panel). We observed a significant upregulation of genes involved in the negative regulation of Wnt signaling (CDH2, GRB10, DACT1, APCDD1, APCDD1L, E2F1), cell-substrate adhesion (COL8A1, ITGA5, LGALS1, SERPINE1, ZYX, ACTA2, CDH2, TGFBI), smooth muscle contraction (ACTA2, ADRA1D, CNN1, MSN, CDC42EP1), p53 downstream pathway (E2F1, SERPINE1, STEAP3), regulation of cell shape (MSN, CDC42EP1, SHROOM3, ACTA2, CDH2, SERPINE1), tissue morphogenesis (ACTA2, ITGA5, MSN, DACT1, SHROOM3, COL8A1, LGALS1), actin cytoskeleton organization (CNN1, INPPL1, ZYX, CDC42EP1, SHROOM3, NEFM), and cell junction organization (CDH2, ITGA5, KIFC3) (Figure 2B, bottom panel). Downregulated genes belong to five main pathways: regulation of reproductive process (BMP4, GJA1, MSX2, SERPINF1, CSDE1, FZD5, CD9, PRKAR2B, CDA, CREG1), cellular response to hormone stimulus (BMP4, GJA1, MSX2, SERPINF1, PRKAR2B, PCSK9, KLF15, KCNS3), cell-cell junction assembly (CD9, GJA1, FZD5, MSX2, PRKAR2B, KCNS3, GNPTAB, SERPINF1), ECM (extracellular matrix) regulators (SERPINF1, SERPINB9, PAMR1) and cellular carbohydrate metabolism process (FAM3C, GNPTAB, PPP1R3B) (Figure 2C, bottom panel). Overall, these transcriptomic analyses unveil that decreasing CSDE1 levels lead to a deregulated expression of genes involved in several pathways, among which, most importantly, the $\mathrm{Wnt} / \beta$-catenin pathway and cellular adhesion exhibit the lowest $\mathrm{p}$-values. 
Inhibition of the $W n t / \beta$-catenin pathway in the fibroblasts of the patient with CSDE1 haploinsufficiency

Our RNA-seq analysis revealed that APCDD1 (APC Down-Regulated 1, MIM \#607479), a component of the $\mathrm{Wnt} / \beta$-catenin pathway is upregulated in the patient's fibroblasts as compared to three healthy individuals (Table S1). As shown in Figure 3A, this significant increase in the expression levels of $A P C D D 1$ was confirmed by RT-qPCR. Western blot analysis on protein samples obtained from fibroblasts of the patient and healthy individuals showed a 2-fold increase of the APCDD1 protein in the patient (Figure $3 \mathrm{~B}$ ). APCDD1 is a direct target of the $\mathrm{Wnt} / \beta$-catenin pathway and the corresponding protein is an essential inhibitor of this pathway, thus exerting a negative feedback control $(47,48)$.

In order to evaluate the state of the Wnt/B-catenin signaling in the patient's fibroblasts, we first assessed through western blot analysis the expression levels of $\beta$-catenin and showed a $\sim 25 \%$ decrease in the $\beta$-catenin levels in the patient as compared to healthy individuals (Figure $3 C$ ), whereas $\beta$-catenin transcripts were unchanged compared to healthy individuals as shown by our RNA-seq analysis. We further quantified the $W n t / \beta$-catenin signaling in fibroblasts from the patient and from healthy individuals using a TOPFlash/FOPFlash luciferase reporter assay that provides a precise measurement of the canonical Wnt-specific transcriptional activity (Figure 3D). Results of this assay showed a significant inhibition of this pathway in the patient, in keeping with the identified decrease of $\beta$-catenin protein levels. Altogether, these data show an increase of $A P C D D 1$ transcripts and protein levels and a subsequent inhibition of the $\mathrm{Wnt} / \beta$-catenin pathway in the patient carrying the CSDE1 null-mutation.

\section{Enhanced substrate adhesion faculties of the fibroblasts of the patient with CSDE1 haploinsufficiency}

As our RNA-seq analysis suggested an alteration of the overall adhesion capacities of the cells of the patient through deregulation of the expression of cadherins and integrins (Figure 2B \& 2C and Table S1), we sought to assess cellular adhesion in the patient's fibroblasts. We first confirmed by RT-qPCR the significant increase, in the patient's fibroblasts, of the expression levels of $\mathrm{CDH} 2$ (cadherin 2 or $n$ cadherin, MIM \#114020), a pivotal actor in cell-cell adhesion as well as of SERPINE1 (Serpin Family E Member 1, MIM \#173360) and ITGA5 (Integrin Alpha-5, MIM \#135620), two genes involved in cellsubstrate adhesion (Figure $3 \mathrm{E}$ ). Noteworthy, $\mathrm{CDH} 2$ is also a regulator of the $\mathrm{Wnt} / \mathrm{\beta}$-catenin pathway. To further investigate the cell-substrate adhesion abilities of the fibroblasts obtained from the patient, we conducted a cell-substrate adhesion assay using a collagen I - coated surface. We observed significant enhanced adhesion abilities of the fibroblasts of the patient as compared to 
those from healthy individuals (Figure 3F). Taken together, these data reveal enhanced cell-substrate adhesion faculties directly through the modulation of CSDE1 target genes. 


\section{DISCUSSION}

In this study, we provide a thorough description of the disease phenotype of a patient with severe IDASD carrying a heterozygous de novo nonsense variation in CSDE1 and followed from birth to the age of 21 years. We performed functional studies aiming at deciphering the CSDE1-dependent pathways involved in the pathophysiology of this highly heterogeneous disease condition. The study of the patient's primary fibroblasts, through a combination of various approaches, indeed revealed impairment of the Wnt/ $\beta$-catenin pathway and of the cellular adhesion abilities that result from a deregulated expression of two specific CSDE1 targets, namely APCDD1 and CDH2. Overall, these data support a pathophysiological model of the disease in which reduced levels of CSDE1 impair the regulation of two of its target transcripts ( $A P C D D 1$ and $C D H 2)$ leading to abnormal levels of the corresponding proteins and therefore deregulation of the associated pathways (Figure 4).

CSDE1 and ID-ASD - The in-depth description of the patient's phenotype, which includes severe developmental delay with no malformations, cognitive impairment, seizures and distinctive morphological characteristics at different stages of his life, represents a major asset for the diagnosis of other CSDE1-related ID-ASD cases. By reviewing the phenotype of the patients so-far reported with a CSDE1 loss-of-function variant, we noticed a variable expressivity of this autosomal dominant disorder, with severity ranging from isolated language impairment in some parents of the patients carrying an inherited CSDE1 mutation to severe ID (36). Such large phenotypic spectrum suggests a potential role of environmental or modifying factors. In this regard, our patient carries another de novo missense variation c.616C>T p.(Leu206Phe) in the GNB2L1 gene. Despite the fact that GNB2L1 is not involved in human ID-ASD pathology, we cannot exclude the possibility that this GNB2L1 variation may have an impact on disease expressivity in our patient. Implication of the homolog of GNB2L1 (Rack1) was suggested in axon guidance in C.elegans (49), in neurite extension of neuronally differentiated rat cells (50), and in axon outgrowth of mouse primary cortical neurons (51).

Among the commonly used patient-derived cellular models for studying neurological disorders (e.g. human dermal fibroblasts, induced pluripotent stem cells, neural cells induced from iPSC or directly from postmitotic somatic cells, immortalized lymphocytes and peripheral leukocytes), we have chosen to conduct our investigations using dermal fibroblasts derived from the patients as they represent a relevant patient-derived cellular model for the study of ID-ASD. Indeed, they have been widely used as patient-derived cellular models for studying several disease conditions affecting the central nervous system (CNS) function as they share molecular similarities with CNS cells and express molecular factors that are highly similar to cells of neuro-ectodermal origin $(52,53)$. Our study establishes the role of CSDE1 in the onset of this ID-ASD in humans based on data obtained from the 
patient's fibroblasts. So far, the involvement of Csde1 in neurodevelopment has been previously suggested by two studies performed in mouse and drosophila models. Csde1 has been implicated in neuronal and synapse development including synapse transmission (36) and has been shown to be crucial for the proper control of the migration of precerebellar neurons (54). Furthermore, our study highlights the role of CSDE1 in human neuronal development as our transcriptomic analysis reveals a significant deregulation of the expression of NEFM (Neurofilament medium polypeptide) in the patient's fibroblasts, a protein belonging to GO: actin cytoskeleton organization and involved in neuron projection development.

CSDE1 is a key regulator of the Wnt/ $\beta$-catenin pathway - Our study shows that the $\mathrm{Wnt} / \beta$-catenin pathway is deregulated upon partial loss of CSDE1 through a mechanism at least partly explained by the modulation of $A P C D D 1$ and $C D H 2$ expression by CSDE1. Several of our data strongly support a downregulation of the Wnt/ $\beta$-catenin pathway in the patient's cells. First, we show that among the diverse CSDE1 direct transcript targets that belong to the $\mathrm{Wnt} / \beta$-catenin network, $A P C D D 1$ and $C D H 2$ are significantly upregulated, $A P C D D 1$ being the transcript with the most deregulated expression as compared to healthy individuals. APCDD1, a target of the $\mathrm{Wnt} / \beta$-catenin pathway also acts as an inhibitor of this pathway by preventing the formation of the Wnt-Fzd-Lrp5/6 (LDL Receptor Related Protein 5/6) receptor complex, thus creating a negative feedback loop on $\mathrm{Wnt} / \beta$-catenin signaling $(47,48)$. $C D H 2$ regulates the availability of key factors of the $W n t / \beta$-catenin signaling like the core protein $\beta$-catenin or the Wnt co-receptor $\operatorname{Lrp6}(55,56)$. Second, our data show decreased levels of the $\beta$-catenin protein in the patient's fibroblasts although the levels of $B$-catenin transcripts are not deregulated, thereby supporting a posttranslational role of CSDE1 in the regulation of $\beta$-catenin. Accordingly, decreased levels of the $\beta$-catenin protein with no deregulation of the 6 -catenin transcripts was observed in Csde1 knock-out mice (36) as well as after CSDE1 silencing in human melanoma cells (30). The discrepancy we observe between the decreased levels of $\beta$-catenin protein and the unchanged levels of the corresponding transcripts is in accordance with the well-established posttranslational regulation of the $\beta$-catenin protein through modulation of its phosphorylation and ubiquitination states (reviewed in (57)). Third, the observed decreased levels of $\beta$-catenin are indeed followed by an overall inhibition of the pathway as shown by our luciferase assay. Overall, CSDE1, which acts as an upstream modulator of the expression of individual effectors of the $\mathrm{Wnt} / \beta$-catenin pathway, plays therefore a pivotal role in the regulation of this pathway.

Alteration of the fine-tuning of the $\mathrm{Wnt} / \boldsymbol{\beta}$-catenin pathway in ID-ASD - The spatiotemporal regulation of the evolutionarily conserved $W n t / \beta$-catenin pathway is crucial for correct neurodevelopmental and post-neurodevelopmental processes; actors of this pathway are involved in 
regionalization of nervous system, differentiation of neural progenitor cells, axon guidance, dendritic development, as well as neuronal migration and plasticity (reviewed in $(3,58)$ ). In consistence with these functions, our study highlights the involvement in ID-ASD pathophysiology of three key players of the $\mathrm{Wnt} / \beta$-catenin signaling pathway: the $\beta$-catenin core element and two modulators of the pathway, APCDD1 and CDH2. Accordingly, specific gene mutations in $\beta$-catenin (CTNNB1) $(10,11,59)$ or $\mathrm{CDH} 2(60)$ have been reported in ID. Furthermore, APCDD1 has been involved in neurological disorders through its roles in oligodendrocyte differentiation and regenerative myelination in the central nervous system (61) as well as in the generation of neurons from progenitors (47). Whereas our data show that the $\mathrm{Wnt} / \mathrm{\beta}$-catenin pathway is downregulated in the ID-ASD patient, both hyperand hypoactivity of this pathway have been shown to alter cognitive functions (reviewed in (62)). Indeed, the deregulated expression of the $\beta$-catenin protein illustrates this duality: several patients with cognitive impairments including ID and ASD present $\beta$-catenin haploinsufficiency $(10,11)$ whereas others exhibit increased $\beta$-catenin levels due to the deletion of the gene encoding the APC (Adenomatous polyposis coli) protein that mediates $\beta$-catenin degradation (63). Modulation of the Wnt/ $\beta$-catenin pathway can also occur in a cell-specific manner as illustrated by the regulation mediated by CHD8 (chromodomain helicase DNA binding protein 8), a protein involved in ASD pathogenesis (64) which acts as a positive regulator of the Wnt $\beta$-catenin pathway in neural progenitor cells (65), and as a negative regulator of this pathway in non-neuronal cell lines.

Overall, these data raise the larger question of the mechanisms by which the altered spatiotemporal fine-tuning of the $\mathrm{Wnt} / \mathrm{\beta}$-catenin pathway contributes to the occurrence of ID-ASD. Several nonexclusive answers can be put forward based on studies performed in mouse and rat models: (i) the $\mathrm{Wnt} / \beta$-catenin pathway plays a key role in the regulation of neuronal polarity and axonal outgrowth through the ligand Wnt3a (66); (ii) it is also important for dendritic morphogenesis via the $\beta$-catenin protein (67); (iii) the Wnt/ $\beta$-catenin pathway is also pivotal for the proper functioning of the neuronal network through the modulation of the neural glucose metabolism. Indeed, by means of a mechanism dependent on the ligand Wnt3a and the metabolic sensor Akt, the $\mathrm{Wnt} / \beta$-catenin pathway regulates the glucose intake in neurons as well as the activity of the hexokinase and the glycolytic rate (68). In keeping with this impact of the Wnt/ $\beta$-catenin pathway on metabolism, our RNA-seq analysis shows a deregulated expression of genes involved in the carbohydrate metabolism.

Enhanced cellular adhesion in a neurodevelopmental disease - Our results unveil a role for CSDE1 in enhanced cellular adhesion in the context of ID-ASD. The implication for CSDE1 in cellular adhesion has so far been reported in the context of cancer progression in melanoma cell models (30), but not in the context of ID-ASD. Most importantly, our transcriptomic analysis performed in patient's 
primary fibroblasts shows the modulation of the expression of genes belonging to the cadherin/protocadherin superfamily and integrin families that control both cell-cell and cell-matrix adhesion. On the one hand, cell-cell adhesion - essentially ensured by molecules belonging to the cadherin and protocadherin superfamily - regulates the formation of both adherens and synaptic junctions in the central nervous system (69). $C D H 2$, a gene known to be essential for proper axon guidance (60), is one of the cell-cell adhesion genes whose expression was found deregulated in our patient. On the other hand, cell-matrix adhesion - under the control of proteins mainly belonging to the integrin family - affects cell migration, axon guidance and synapse formation in the central nervous systems (70-72). Among the integrins, ITGA5 - significantly deregulated in the fibroblasts of our patient - is known to contribute to the survival and proliferation of glial progenitor cells (73). Moreover, the integrin-mediated cell interactions are tightly regulated by plasminogen activators like SERPINE1 (74) that is significantly upregulated in the fibroblasts of our patient. Neurological impairments can result from deregulation of cell-cell or cell-substrate adhesion (reviewed in $(69,75)$. Overall, our data support a key role for CSDE1 in the regulation of these two cell adhesion types, a result that is in line with the wide-ranging neurological phenotype observed in the patient (epilepsy and cognitive, motor, behavioral impairments).

In summary, our work identifies the $\mathrm{Wnt} / \mathrm{B}$-catenin signaling and cellular adhesion as two major deregulated pathways in an ID-ASD patient carrying a monoallelic null mutation in CSDE1 through mechanisms relying on $A P C D D 1$ and $C D H 2$. In addition, by providing an in-depth description of the phenotype of the patient at different stages of his life, our study should help identifying patients with ID-ASD who could benefit from a screening for CSDE1 mutations. 


\section{ACKNOWLEDGEMENTS}

We thank the patient and his family as well as control individuals for their cooperation. We thank Virginie Bordereau and Patrick Raymond for their technical contributions and Marthe Rizk-Rabin and Bruno Ragazzon for the material and advice on the functional assessing of the $\mathrm{Wnt} / \beta$-catenin pathway. This work was supported by grants from the Foundation of rare diseases (GIS - Institut des Maladies Rares).

\section{CONFLICT OF INTEREST}

The authors have no conflict of interest to declare. 


\section{REFERENCES}

1. Aspromonte MC, Bellini M, Gasparini A, Carraro M, Bettella E, Polli R, et al. Characterization of intellectual disability and autism comorbidity through gene panel sequencing. Hum Mutat. 2019;40(9):1346-63.

2. Srivastava AK, Schwartz CE. Intellectual disability and autism spectrum disorders: causal genes and molecular mechanisms. Neurosci Biobehav Rev. 2014 Oct;46 Pt 2:161-74.

3. Kumar S, Reynolds K, Ji Y, Gu R, Rai S, Zhou CJ. Impaired neurodevelopmental pathways in autism spectrum disorder: a review of signaling mechanisms and crosstalk. $\mathrm{J}$ Neurodev Disord. 2019 Jun 15;11(1):10.

4. Lin P-I, Chien Y-L, Wu Y-Y, Chen C-H, Gau SS-F, Huang Y-S, et al. The WNT2 gene polymorphism associated with speech delay inherent to autism. Res Dev Disabil. 2012 Oct;33(5):1533-40.

5. Marui T, Funatogawa I, Koishi S, Yamamoto K, Matsumoto H, Hashimoto O, et al. Association between autism and variants in the wingless-type MMTV integration site family member 2 ( WNT2) gene. Int J Neuropsychopharmacol. 2010 May;13(4):443-9.

6. Martin P-M, Yang X, Robin N, Lam E, Rabinowitz JS, Erdman CA, et al. A rare WNT1 missense variant overrepresented in ASD leads to increased Wnt signal pathway activation. Transl Psychiatry. 2013 Sep 3;3:e301.

7. Wassink TH, Piven J, Vieland VJ, Huang J, Swiderski RE, Pietila J, et al. Evidence supporting WNT2 as an autism susceptibility gene. Am J Med Genet. 2001 Jul 8;105(5):406-13.

8. De Rubeis S, He X, Goldberg AP, Poultney CS, Samocha K, Cicek AE, et al. Synaptic, transcriptional and chromatin genes disrupted in autism. Nature. $2014 \mathrm{Nov}$ 13;515(7526):209-15.

9. Iossifov I, O’Roak BJ, Sanders SJ, Ronemus M, Krumm N, Levy D, et al. The contribution of de novo coding mutations to autism spectrum disorder. Nature. 2014 Nov 13;515(7526):216-21.

10. Dubruc E, Putoux A, Labalme A, Rougeot C, Sanlaville D, Edery P. A new intellectual disability syndrome caused by CTNNB1 haploinsufficiency. Am J Med Genet A. 2014 Jun;164A(6):1571-5.

11. Kuechler A, Willemsen MH, Albrecht B, Bacino CA, Bartholomew DW, van Bokhoven $\mathrm{H}$, et al. De novo mutations in beta-catenin (CTNNB1) appear to be a frequent cause of intellectual disability: expanding the mutational and clinical spectrum. Hum Genet. 2015 Jan;134(1):97-109.

12. O’Roak BJ, Vives L, Girirajan S, Karakoc E, Krumm N, Coe BP, et al. Sporadic autism exomes reveal a highly interconnected protein network of de novo mutations. Nature. 2012 Apr 4;485(7397):246-50. 
13. Krumm N, O'Roak BJ, Shendure J, Eichler EE. A de novo convergence of autism genetics and molecular neuroscience. Trends Neurosci. 2014 Feb;37(2):95-105.

14. Myrick LK, Deng P-Y, Hashimoto H, Oh YM, Cho Y, Poidevin MJ, et al. Independent role for presynaptic FMRP revealed by an FMR1 missense mutation associated with intellectual disability and seizures. Proc Natl Acad Sci USA. 2015 Jan 27;112(4):949_ 56.

15. Addington AM, Gauthier J, Piton A, Hamdan FF, Raymond A, Gogtay N, et al. A novel frameshift mutation in UPF3B identified in brothers affected with childhood onset schizophrenia and autism spectrum disorders. Mol Psychiatry. 2011 Mar;16(3):238-9.

16. Bardoni B, Abekhoukh S, Zongaro S, Melko M. Intellectual disabilities, neuronal posttranscriptional RNA metabolism, and RNA-binding proteins: three actors for a complex scenario. Prog Brain Res. 2012;197:29-51.

17. Jolly LA, Homan CC, Jacob R, Barry S, Gecz J. The UPF3B gene, implicated in intellectual disability, autism, ADHD and childhood onset schizophrenia regulates neural progenitor cell behaviour and neuronal outgrowth. Hum Mol Genet. 2013 Dec $1 ; 22(23): 4673-87$.

18. Laumonnier F, Shoubridge C, Antar C, Nguyen LS, Van Esch H, Kleefstra T, et al. Mutations of the UPF3B gene, which encodes a protein widely expressed in neurons, are associated with nonspecific mental retardation with or without autism. Mol Psychiatry. $2010 \mathrm{Jul} ; 15(7): 767-76$.

19. Nguyen LS, Kim H-G, Rosenfeld JA, Shen Y, Gusella JF, Lacassie Y, et al. Contribution of copy number variants involving nonsense-mediated mRNA decay pathway genes to neuro-developmental disorders. Hum Mol Genet. 2013 May $1 ; 22(9): 1816-25$.

20. Perou R, Bitsko RH, Blumberg SJ, Pastor P, Ghandour RM, Gfroerer JC, et al. Mental health surveillance among children--United States, 2005-2011. MMWR Suppl. 2013 May 17;62(2):1-35.

21. Maulik PK, Mascarenhas MN, Mathers CD, Dua T, Saxena S. Prevalence of intellectual disability: a meta-analysis of population-based studies. Res Dev Disabil. 2011 Apr;32(2):419-36.

22. Bourke J, de Klerk N, Smith T, Leonard H. Population-Based Prevalence of Intellectual Disability and Autism Spectrum Disorders in Western Australia: A Comparison With Previous Estimates. Medicine (Baltimore). 2016 May;95(21):e3737.

23. Amiel J, Rio M, de Pontual L, Redon R, Malan V, Boddaert N, et al. Mutations in TCF4, encoding a class I basic helix-loop-helix transcription factor, are responsible for PittHopkins syndrome, a severe epileptic encephalopathy associated with autonomic dysfunction. Am J Hum Genet. 2007 May;80(5):988-93.

24. Zweier C, Peippo MM, Hoyer J, Sousa S, Bottani A, Clayton-Smith J, et al. Haploinsufficiency of TCF4 causes syndromal mental retardation with intermittent hyperventilation (Pitt-Hopkins syndrome). Am J Hum Genet. 2007 May;80(5):9941001. 
25. Grosset C, Chen CY, Xu N, Sonenberg N, Jacquemin-Sablon H, Shyu AB. A mechanism for translationally coupled mRNA turnover: interaction between the poly(A) tail and a c-fos RNA coding determinant via a protein complex. Cell. 2000 Sep 29;103(1):29-40.

26. Ray S, Anderson EC. Stimulation of translation by human Unr requires cold shock domains 2 and 4, and correlates with poly(A) binding protein interaction. Sci Rep. 2016 Mar 3;6:22461.

27. Mitchell SA, Brown EC, Coldwell MJ, Jackson RJ, Willis AE. Protein factor requirements of the Apaf-1 internal ribosome entry segment: roles of polypyrimidine tract binding protein and upstream of N-ras. Mol Cell Biol. 2001 May;21(10):3364-74.

28. Tinton SA, Schepens B, Bruynooghe Y, Beyaert R, Cornelis S. Regulation of the cellcycle-dependent internal ribosome entry site of the PITSLRE protein kinase: roles of Unr (upstream of N-ras) protein and phosphorylated translation initiation factor eIF2alpha. Biochem J. 2005 Jan 1;385(Pt 1):155-63.

29. Schepens B, Tinton SA, Bruynooghe Y, Parthoens E, Haegman M, Beyaert R, et al. A role for hnRNP C1/C2 and Unr in internal initiation of translation during mitosis. EMBO J. 2007 Jan 10;26(1):158-69.

30. Wurth L, Papasaikas P, Olmeda D, Bley N, Calvo GT, Guerrero S, et al. UNR/CSDE1 Drives a Post-transcriptional Program to Promote Melanoma Invasion and Metastasis. Cancer Cell. 2016 Nov 14;30(5):694-707.

31. Ju Lee H, Bartsch D, Xiao C, Guerrero S, Ahuja G, Schindler C, et al. A posttranscriptional program coordinated by CSDE1 prevents intrinsic neural differentiation of human embryonic stem cells. Nat Commun. 2017;8:1456.

32. Elatmani H, Dormoy-Raclet V, Dubus P, Dautry F, Chazaud C, Jacquemin-Sablon H. The RNA-binding protein Unr prevents mouse embryonic stem cells differentiation toward the primitive endoderm lineage. Stem Cells. 2011 Oct;29(10):1504-16.

33. Guo A-X, Cui J-J, Wang L-Y, Yin J-Y. The role of CSDE1 in translational reprogramming and human diseases. Cell Commun Signal. 2020 Jan 27;18(1):14.

34. Sanders SJ, Murtha MT, Gupta AR, Murdoch JD, Raubeson MJ, Willsey AJ, et al. De novo mutations revealed by whole-exome sequencing are strongly associated with autism. Nature. 2012 Apr 4;485(7397):237-41.

35. Xia K, Guo H, Hu Z, Xun G, Zuo L, Peng Y, et al. Common genetic variants on 1p13.2 associate with risk of autism. Mol Psychiatry. 2014 Nov;19(11):1212-9.

36. Guo H, Li Y, Shen L, Wang T, Jia X, Liu L, et al. Disruptive variants of CSDE1 associate with autism and interfere with neuronal development and synaptic transmission. Sci Adv. 2019 Sep;5(9):eaax2166.

37. Thomas L, Bouhouche K, Whitfield M, Thouvenin G, Coste A, Louis B, et al. TTC12 Loss-of-Function Mutations Cause Primary Ciliary Dyskinesia and Unveil Distinct Dynein Assembly Mechanisms in Motile Cilia Versus Flagella. Am J Hum Genet. 2020 06;106(2):153-69. 
38. Whalen S, Héron D, Gaillon T, Moldovan O, Rossi M, Devillard F, et al. Novel comprehensive diagnostic strategy in Pitt-Hopkins syndrome: clinical score and further delineation of the TCF4 mutational spectrum. Hum Mutat. 2012 Jan;33(1):64-72.

39. Drévillon L, Megarbane A, Demeer B, Matar C, Benit P, Briand-Suleau A, et al. KBPcytoskeleton interactions underlie developmental anomalies in Goldberg-Shprintzen syndrome. Hum Mol Genet. 2013 Jun 15;22(12):2387-99.

40. Dobin A, Davis CA, Schlesinger F, Drenkow J, Zaleski C, Jha S, et al. STAR: ultrafast universal RNA-seq aligner. Bioinformatics. 2013 Jan 1;29(1):15-21.

41. Noli L, Capalbo A, Ogilvie C, Khalaf Y, Ilic D. Discordant Growth of Monozygotic Twins Starts at the Blastocyst Stage: A Case Study. Stem Cell Reports. 2015 Dec 8;5(6):946-53.

42. Zhou Y, Zhou B, Pache L, Chang M, Khodabakhshi AH, Tanaseichuk O, et al. Metascape provides a biologist-oriented resource for the analysis of systems-level datasets. Nat Commun. 2019 03;10(1):1523.

43. Hsu M-K, Lin H-Y, Chen F-C. NMD Classifier: A reliable and systematic classification tool for nonsense-mediated decay events. PLoS One. 2017;12(4):e0174798.

44. Brogna S, Wen J. Nonsense-mediated mRNA decay (NMD) mechanisms. Nat Struct Mol Biol. 2009 Feb;16(2):107-13.

45. Bisgaard A-M, Rasmussen LN, Møller HU, Kirchhoff M, Bryndorf T. Interstitial deletion of the short arm of chromosome $1(1 \mathrm{p} 13.1 \mathrm{p} 21.1)$ in a girl with mental retardation, short stature and colobomata. Clin Dysmorphol. 2007 Apr;16(2):109-12.

46. Fitzgibbon GJ, Kingston H, Needham M, Gaunt L. Haploinsufficiency of the nerve growth factor beta gene in a 1p13 deleted female child with an insensitivity to pain. Dev Med Child Neurol. 2009 Oct;51(10):833-7.

47. Shimomura Y, Agalliu D, Vonica A, Luria V, Wajid M, Baumer A, et al. APCDD1 is a novel Wnt inhibitor mutated in hereditary hypotrichosis simplex. Nature. 2010 Apr 15;464(7291):1043-7.

48. Takahashi M, Fujita M, Furukawa Y, Hamamoto R, Shimokawa T, Miwa N, et al. Isolation of a novel human gene, APCDD1, as a direct target of the beta-Catenin/T-cell factor 4 complex with probable involvement in colorectal carcinogenesis. Cancer Res. 2002 Oct 15;62(20):5651-6.

49. Demarco RS, Lundquist EA. RACK-1 acts with Rac GTPase signaling and UNC115/abLIM in Caenorhabditis elegans axon pathfinding and cell migration. PLoS Genet. 2010 Nov 18;6(11):e1001215.

50. Dwane S, Durack E, O'Connor R, Kiely PA. RACK1 promotes neurite outgrowth by scaffolding AGAP2 to FAK. Cell Signal. 2014 Jan;26(1):9-18.

51. Kershner L, Welshhans K. RACK1 is necessary for the formation of point contacts and regulates axon growth. Dev Neurobiol. 2017;77(9):1038-56. 
52. Kálmán S, Garbett KA, Janka Z, Mirnics K. Human dermal fibroblasts in psychiatry research. Neuroscience. 2016 Apr 21;320:105-21.

53. Rieske P, Krynska B, Azizi SA. Human fibroblast-derived cell lines have characteristics of embryonic stem cells and cells of neuro-ectodermal origin. Differentiation. 2005 Dec;73(9-10):474-83.

54. Kobayashi H, Kawauchi D, Hashimoto Y, Ogata T, Murakami F. The control of precerebellar neuron migration by RNA-binding protein Csde1. Neuroscience. $2013 \mathrm{Dec}$ 3;253:292-303.

55. Revollo L, Kading J, Jeong SY, Li J, Salazar V, Mbalaviele G, et al. N-cadherin restrains PTH activation of Lrp6/ $\beta$-catenin signaling and osteoanabolic action. J Bone Miner Res. 2015 Feb;30(2):274-85.

56. Shin CS, Her S-J, Kim J-A, Kim DH, Kim SW, Kim SY, et al. Dominant negative Ncadherin inhibits osteoclast differentiation by interfering with beta-catenin regulation of RANKL, independent of cell-cell adhesion. J Bone Miner Res. 2005 Dec;20(12):220012.

57. Gao C, Xiao G, Hu J. Regulation of Wnt/ $/$-catenin signaling by posttranslational modifications. Cell Biosci. 2014 Mar 4;4(1):13.

58. Kwan V, Unda BK, Singh KK. Wnt signaling networks in autism spectrum disorder and intellectual disability. J Neurodev Disord. 2016;8:45.

59. Dong F, Jiang J, McSweeney C, Zou D, Liu L, Mao Y. Deletion of CTNNB1 in inhibitory circuitry contributes to autism-associated behavioral defects. Hum Mol Genet. 2016 01;25(13):2738-51.

60. Accogli A, Calabretta S, St-Onge J, Boudrahem-Addour N, Dionne-Laporte A, Joset P, et al. De Novo Pathogenic Variants in N-cadherin Cause a Syndromic Neurodevelopmental Disorder with Corpus Collosum, Axon, Cardiac, Ocular, and Genital Defects. Am J Hum Genet. 2019 Oct 3;105(4):854-68.

61. Lee HK, Laug D, Zhu W, Patel JM, Ung K, Arenkiel BR, et al. Apcdd1 stimulates oligodendrocyte differentiation after white matter injury. Glia. 2015 Oct;63(10):1840-9.

62. Kalkman HO. A review of the evidence for the canonical Wnt pathway in autism spectrum disorders. Mol Autism. 2012 Oct 19;3(1):10.

63. Barber JC, Ellis KH, Bowles LV, Delhanty JD, Ede RF, Male BM, et al. Adenomatous polyposis coli and a cytogenetic deletion of chromosome 5 resulting from a maternal intrachromosomal insertion. J Med Genet. 1994 Apr;31(4):312-6.

64. Bernier R, Golzio C, Xiong B, Stessman HA, Coe BP, Penn O, et al. Disruptive CHD8 mutations define a subtype of autism early in development. Cell. $2014 \mathrm{Jul}$ $17 ; 158(2): 263-76$.

65. Durak O, Gao F, Kaeser-Woo YJ, Rueda R, Martorell AJ, Nott A, et al. Chd8 mediates cortical neurogenesis via transcriptional regulation of cell cycle and Wnt signaling. Nat Neurosci. 2016;19(11):1477-88. 
66. Stanganello E, Zahavi EE, Burute M, Smits J, Jordens I, Maurice MM, et al. Wnt Signaling Directs Neuronal Polarity and Axonal Growth. iScience. 2019 Mar 29;13:31827.

67. Yu X, Malenka RC. Beta-catenin is critical for dendritic morphogenesis. Nat Neurosci. 2003 Nov;6(11):1169-77.

68. Cisternas P, Salazar P, Silva-Álvarez C, Barros LF, Inestrosa NC. Activation of Wnt Signaling in Cortical Neurons Enhances Glucose Utilization through Glycolysis. J Biol Chem. 2016 Dec 9;291(50):25950-64.

69. Redies C, Hertel N, Hübner CA. Cadherins and neuropsychiatric disorders. Brain Res. 2012 Aug 27;1470:130-44.

70. Ringer P, Colo G, Fässler R, Grashoff C. Sensing the mechano-chemical properties of the extracellular matrix. Matrix Biol. 2017;64:6-16.

71. Reichardt LF, Tomaselli KJ. Extracellular matrix molecules and their receptors: functions in neural development. Annu Rev Neurosci. 1991;14:531-70.

72. Schmid RS, Anton ES. Role of integrins in the development of the cerebral cortex. Cereb Cortex. 2003 Mar;13(3):219-24.

73. Haack H, Hynes RO. Integrin receptors are required for cell survival and proliferation during development of the peripheral glial lineage. Dev Biol. 2001 May 1;233(1):38-55.

74. Wang L, Ly CM, Ko C-Y, Meyers EE, Lawrence DA, Bernstein AM. uPA binding to PAI-1 induces corneal myofibroblast differentiation on vitronectin. Invest Ophthalmol Vis Sci. 2012 Jul 13;53(8):4765-75.

75. Jaudon F, Thalhammer A, Cingolani LA. Integrin adhesion in brain assembly: From molecular structure to neuropsychiatric disorders. Eur J Neurosci. 2020 Jun 12; https://doi.org/10.1111/ejn.14859. 


\section{FIGURE LEGENDS}

\section{Figure 1. The patient's clinical features and the molecular bases of the CSDE1 haploinsufficiency}

A. Phenotypic features of the patient - Front and profile view of individual II.1 at $5(a, b)$ and 21 years $(c, d)$ of age showing the distinct facial features. Photos of the patient at age 21 showing the (e) pectus excavatum, (f) his hand and $(g, h)$ his foot.

B. Genealogical tree of the patient with ID-ASD (Individual II.1) and his parents (Individuals I.1 and

I.2). Electropherograms from Sanger sequencing showing the heterozygous c.362C $>$ A p.(Ser121*) mutation only in individual II.1 and not in his parents.

C. Sanger sequencing of CDNA obtained from fibroblasts of healthy individuals and individual II.1 upon cycloheximide treatment ( $30 \mathrm{\mu g} / \mathrm{ml}$, for 4 hours) showing accumulation of the mutated CSDE1 transcripts.

D. Quantification of CSDE1 transcripts from fibroblasts of three healthy individuals and individual II.1 by RT-qPCR. The transcript levels of CSDE1 were normalized to the housekeeping gene ERCC3. The results are shown as the mean of three independent experiments \pm SEM and plotted relative to the healthy controls conditions.

E. CSDE1 protein expression in fibroblasts of healthy individuals and individual II.1 - Equal amounts of protein extracts were subjected to SDS-PAGE and immunoblotted with CSDE1 antibody. The CSDE1 signal was quantified with ImageJ software and normalized to the amount of GAPDH used as a loading control. The results are shown as the mean of three independent experiments and are plotted as a percentage of the healthy controls condition.

For all experiments, asterisks indicate that the mean is significantly different; $*$ : t test $p$ value $<0.05$, ${ }^{* *}$ : $\mathrm{t}$ test $\mathrm{p}$ value $<0.01,{ }^{* * *}: \mathrm{t}$ test $\mathrm{p}$ value $<0.001$

\section{Figure 2. Transcriptomic analysis in the patient's fibroblasts}

A. Enrichment analysis of RNA-seq data sets - Bar graph of enriched terms across input gene lists, colored by $p$-values and showing biological processes enrichment analysis of up-regulated genes (left panel) and for down-regulated genes (right panel).

B. Analysis of the common upregulated genes from our transcriptomic study and Ju Lee et al. (31).

C. Analysis of the common downregulated genes from our transcriptomic study and Ju Lee et al. (31). Network of enriched terms colored by cluster identity, where nodes that share the same cluster ID are typically close to each other. The p-value corresponding to each enriched term is indicated in brackets; terms containing more genes tend to have a more significant $p$-value. All graphs were generated by Metascape (http://metascape.org, (42)) and were modified graphically only. 
Figure 3. Deregulation of the $\mathrm{Wnt} / \boldsymbol{\beta}$-catenin pathway and cellular adhesion in the patient

A. Quantification of $A P C D D 1$ transcripts from fibroblasts of three healthy individuals and individual II.1 by RT-qPCR. The transcript levels of APCDD1 were normalized to the housekeeping gene ERCC3. The results are shown as the mean of three independent experiments \pm SEM and plotted relative to the healthy controls conditions.

B. APCDD1 protein expression in fibroblasts of three healthy individuals and individual II.1 - Equal amounts of protein extracts were subjected to SDS-PAGE and immunoblotted with the indicated antibody. The APCDD1 signal was quantified with ImageJ software and normalized to the amount of GAPDH used as a loading control. The results are shown as the mean of three independent experiments and are plotted as a percentage of the healthy controls condition. Note: Samples from figure $1 \mathrm{E}$ and $3 \mathrm{~B}$ were loaded on the same gel and different parts of the membrane were revealed with different antibodies, therefore, the GAPDH loading control is the same for figure $1 \mathrm{E}$ and $3 \mathrm{~B}$.

C. $\beta$-catenin protein expression in fibroblasts of three healthy individuals and individual II.1. - Equal amounts of protein extracts were subjected to SDS-PAGE and immunoblotted with the indicated antibody. $\beta$-catenin signal was quantified with ImageJ software and normalized to the amount of $\beta$ tubulin used as a loading control. The results are shown as the mean of three independent experiments and are plotted as a percentage of the healthy controls condition.

D. Quantification of the $\mathrm{Wnt} / \beta$-catenin signaling in fibroblasts from the patient and from healthy individuals using a TOPFlash/FOPFlash luciferase reporter assay - Fibroblasts of healthy individuals and individual II.1 were transfected with TOP or FOP plasmids then 20 hours later treated with 20 $\mathrm{mM} \mathrm{LiCl}$ for 6 hours. Luciferase activity was normalized to total protein amounts and plotted as 4 independent experiments.

E. Quantification of $C D H 2$, SERPINE1 and ITGA5 transcripts from fibroblasts of three healthy individuals and individual II.1 by RT-qPCR. The transcript levels of the mentioned genes were normalized to the housekeeping gene ERCC3. The results are shown as the mean of three independent experiments \pm SEM and are plotted relative to the healthy controls conditions.

F. Cell-substrate adhesion assay in fibroblasts of healthy individuals and individual II.1 - Fibroblasts were harvested on Collagen-I coated plates and the number of cells was quantified by MTT assay. The results are shown as the ratio of number of adherent cells on the number of total cells seeded and are plotted as five independent experiments.

For all experiments, asterisks indicate that the mean is significantly different; * $\mathrm{t}$ test $\mathrm{p}$ value $<0.05$, ${ }^{* *}$ : $\mathrm{t}$ test $\mathrm{p}$ value $<0.01,{ }^{* * *}$ : $\mathrm{t}$ test $\mathrm{p}$ value $<0.001$ 
Figure 4. Pathophysiological model of the CSDE1-haploinsufficiency-related disease

Upper panel - In healthy individuals the levels of CSDE1 mRNA and its corresponding proteins are normal. CSDE1 proteins interact with the IRES, the 5'UTR or the $3^{\prime}$ UTR of their target transcripts to regulate their translation or their stability. In the case of $A P C D D 1$ and $C D H 2$, this interaction would lead to the regulation of the transcripts abundance. Normal amounts of APCDD1 and CDH2 proteins control the homeostasis of specific cellular pathways.

Lower panel - In the ID-ASD patient, the heterozygous nonsense mutation in CSDE1 leads to mRNA decay of the transcripts that carry it. This results in CSDE1 protein haploinsufficiency which will compromise the regulation of the target transcripts (e.g. APCDD1 and $C D H 2$ ) and consequently the levels of the corresponding proteins. Increased levels of APCDD1 and CDH2 proteins lead to the downregulation of the $\mathrm{Wnt} / \beta$-catenin pathway and the increase of cellular adhesion.

\section{TABLE LEGEND}

Phenotype and features of the individual II.I carrying the c.362C>A, p.(Ser121*) variation in CSDE1 compared to patients lacking the chromosomal region that contains CSDE1 (del 1p13.1p13.2, (46) and del 1p13.1p21.1 (45)) and patients presenting mutations in CSDE1 (7 frameshift, 6 stopgain, 3 splicing mutations (36)); n.d. : not defined; ${ }^{\S}$ : The molecular anomalies are present at the heterozygous state. 
Table 1

\begin{tabular}{|c|c|c|c|c|}
\hline Study & Our study & Bisgaard et. al 2007 & $\begin{array}{l}\text { Fitzgibbon et al. } \\
2009\end{array}$ & Guo et. al 2019 \\
\hline Molecular anomalies ${ }^{\S}$ & $\begin{array}{l}\text { c. } 362 C>A \text { p. }\left(\text { Ser } 121^{*}\right) \\
\text { in CSDE1 } \\
\text { c. } 616 C>T \\
\text { p.(Leu206Phe) in } \\
\text { GNB2L1 }\end{array}$ & del 1p13.1p21.1 & del 1p13.1p13.2 & $\begin{array}{l}7 \text { frameshift, } 6 \\
\text { stopgain, } \\
3 \text { splicing mutations } \\
\text { in CSDE1 }\end{array}$ \\
\hline Gender, age & $\begin{array}{l}\text { Male, from birth to } \\
21 \text { years old }\end{array}$ & Female, 13 years old & Female, 5 years old & $\begin{array}{l}11 \text { males, } 6 \text { females } \\
3 \text { to } 19 \text { years old }\end{array}$ \\
\hline Height & $-2 S D$ & $<5$ th centile & n.d. & $\begin{array}{l}\text { 8/15: short (7), tall } \\
(1)\end{array}$ \\
\hline Weight & $-2 S D$ & $\begin{array}{l}\text { Weight-for-height : } \\
\text { 50th centile }\end{array}$ & n.d. & $\begin{array}{l}\text { 6/15: overweight ( } 3) \text {, } \\
\text { lean (3) }\end{array}$ \\
\hline Head Circumference & OSD & $<3$ rd centile & n.d. & 6/14: macrocephaly \\
\hline \multicolumn{5}{|l|}{$\begin{array}{l}\text { Neurodevelopmental } \\
\text { features }\end{array}$} \\
\hline Intellectual disability & Severe & Severe & Severe & $\begin{array}{l}\text { 3/17: below average } \\
\text { or learning disability, } \\
\text { 14/17: mild to severe } \\
\text { ID }\end{array}$ \\
\hline Language impairment & Yes & Yes & Yes & $17 / 17$ \\
\hline $\begin{array}{l}\text { Motor development } \\
\text { delay }\end{array}$ & Walked at 8 years & Yes & Yes & $15 / 17$ \\
\hline \multicolumn{5}{|l|}{ Neurological features } \\
\hline Epilepsy & Yes & Yes & n.d. & $7 / 16$ \\
\hline $\begin{array}{l}\text { Brain MRI } \\
\text { abnormalities }\end{array}$ & No & Delayed myelination & n.d. & $\begin{array}{l}7 / 14 \text { (delayed } \\
\text { myelination :1) }\end{array}$ \\
\hline \multicolumn{5}{|l|}{ Facial features } \\
\hline Telecanthus & Yes & n.d. & Mild & n.d. \\
\hline Long eyebrows & Yes & Yes & Yes & n.d. \\
\hline Epicanthic folds & Yes & No & No & n.d. \\
\hline $\begin{array}{l}\text { Short palpebral } \\
\text { fissures }\end{array}$ & Yes & No & No & n.d. \\
\hline Short/broad nose & Yes & Yes & Yes & n.d. \\
\hline Macrostomia & Yes & Yes & No & n.d. \\
\hline Philtrum & Short & Short & Long & n.d. \\
\hline Low set ears & Yes & Yes & n.d. & n.d. \\
\hline \multicolumn{5}{|l|}{$\begin{array}{l}\text { Musculoskeletal } \\
\text { abnormalities }\end{array}$} \\
\hline Amyotrophy & Yes & n.d. & n.d. & n.d. \\
\hline Hypotonia & Yes & Yes & Yes & $6 / 13$ \\
\hline Pectus excavatum & Yes & n.d. & n.d. & n.d. \\
\hline Genu flexum & Yes & n.d. & n.d. & n.d. \\
\hline
\end{tabular}




\begin{tabular}{|c|c|c|c|c|}
\hline Hand deformities & Mild camptodactyly & n.d. & n.d. & $\begin{array}{l}\text { 6/15: brachydactyly, } \\
\text { polydactyly, and } \\
\text { clinodactyly }\end{array}$ \\
\hline Feet deformities & Brachydactyly & Syndactyly & n.d. & n.d. \\
\hline \multicolumn{5}{|l|}{$\begin{array}{l}\text { Behavior } \\
\text { characteristics }\end{array}$} \\
\hline Repetitive behavior & Yes & n.d. & n.d. & $14 / 15$ \\
\hline ADHD & No & n.d. & n.d. & $9 / 13$ \\
\hline Aggressive behavior & No & n.d. & n.d. & $2 / 14$ \\
\hline $\begin{array}{l}\text { Self-injurious } \\
\text { behavior }\end{array}$ & No & n.d. & No & $3 / 12$ \\
\hline Obsessive behavior & No & n.d. & n.d. & $4 / 13$ \\
\hline Anxiety & No & n.d. & n.d. & $7 / 13$ \\
\hline \multicolumn{5}{|l|}{ Other anomalies } \\
\hline Eye abnormality & Divergent squint & $\begin{array}{l}\text { Iris coloboma - Left } \\
\text { alternating divergent } \\
\text { squint }\end{array}$ & n.d. & $\begin{array}{l}7 / 13 / \text { iris coloboma, } \\
\text { hyperopia, and/or } \\
\text { strabismus }\end{array}$ \\
\hline $\begin{array}{l}\text { Gastrointestinal } \\
\text { problems }\end{array}$ & $\begin{array}{l}\text { Constipation / } \\
\text { diarrhea }\end{array}$ & $\begin{array}{l}\text { Failure to } \\
\text { thrive/gastrostomy } \\
\text { at the age of } 8\end{array}$ & Constipation & $\begin{array}{l}\text { 2/15: intermittent } \\
\text { constipation/diarrhe } \\
\text { a, constipation }\end{array}$ \\
\hline Other & $\begin{array}{l}\text { Lymphomatoid } \\
\text { papulosis, testicular } \\
\text { ectopia, scoliosis }\end{array}$ & & Pain insensibility & \\
\hline
\end{tabular}


Figures

Figure 1
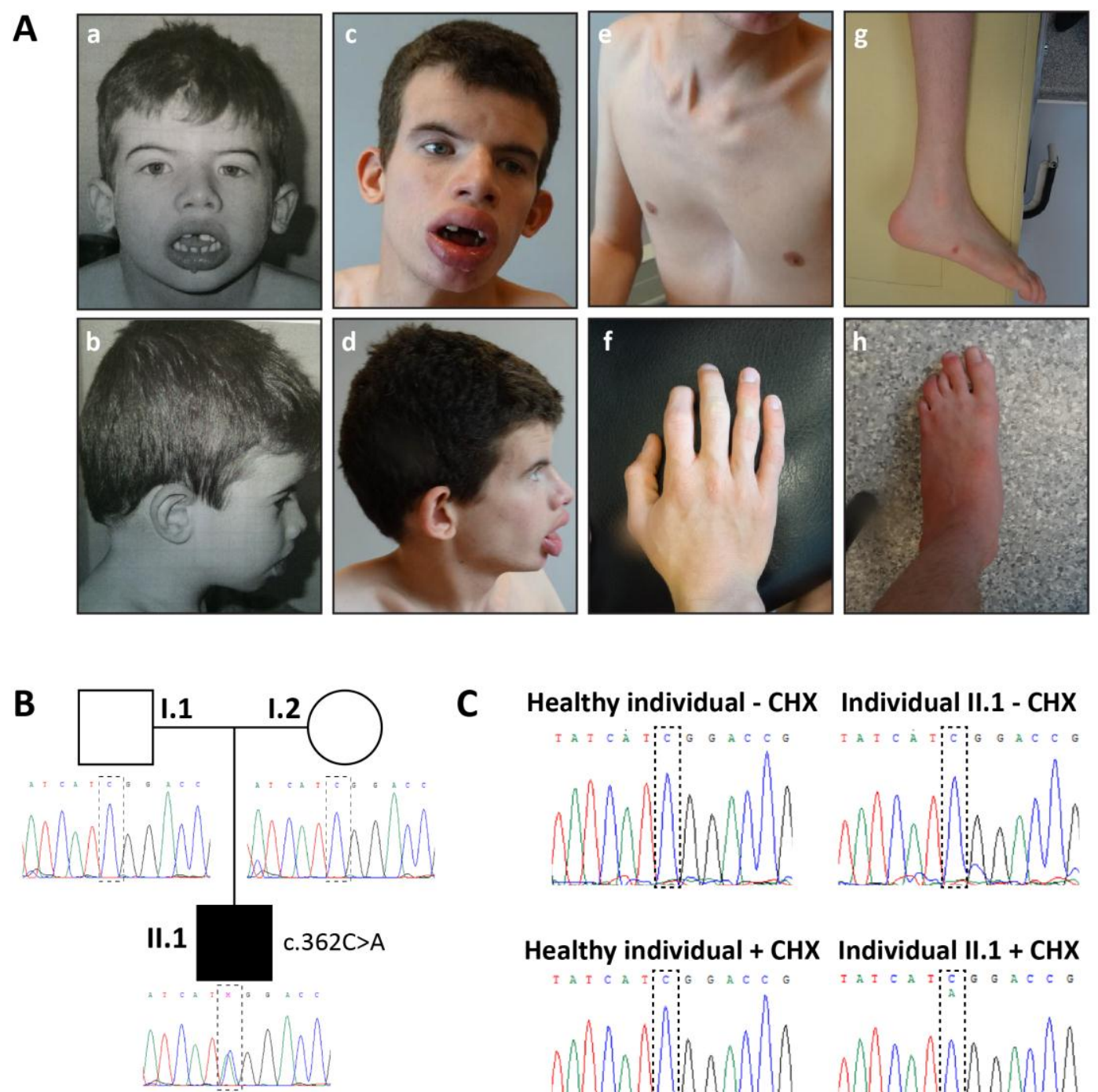

Healthy individual + CHX Individual II.1 + CHX
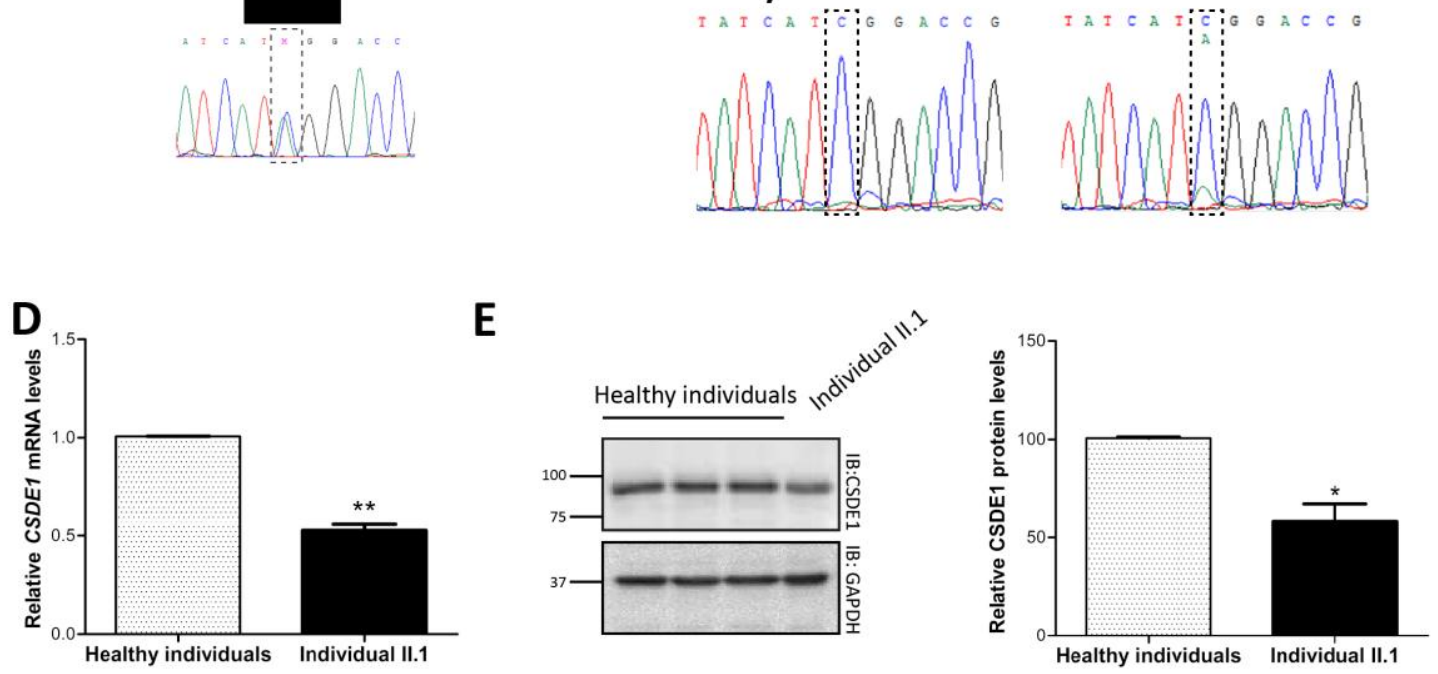


\section{Figure 2}

A Gene set enrichment analysis of upregulated terms

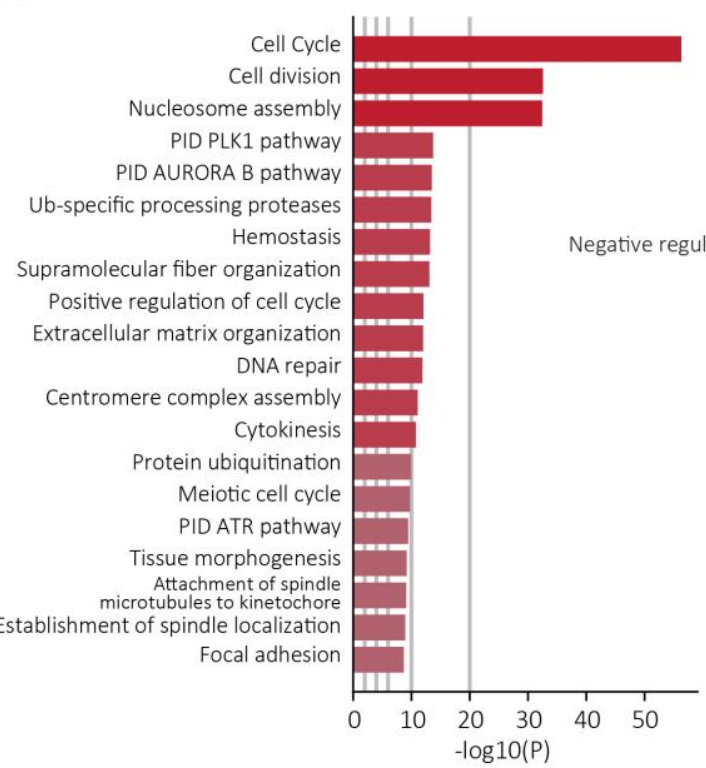

Gene set enrichment analysis of downregulated terms

Homophilic cell adhesion via plasm

membrane adhesion molecules

Vasculature development Response to oxidative stress

Keratan sulfate degradation

Cellular response to toxic substanc

Behavio

intracellular signal transduction PID P53 downstream pathway Regulated exocytosis Ferroptosis

Platelet degranulation NABA matriosome associate Regulation of leukocyte migration

Cofactor metabolic process Regulation of protein transport

Fatty acid metabolic proces Lipid catabolic proces Regulation of peptidase activity Response to acid chemica

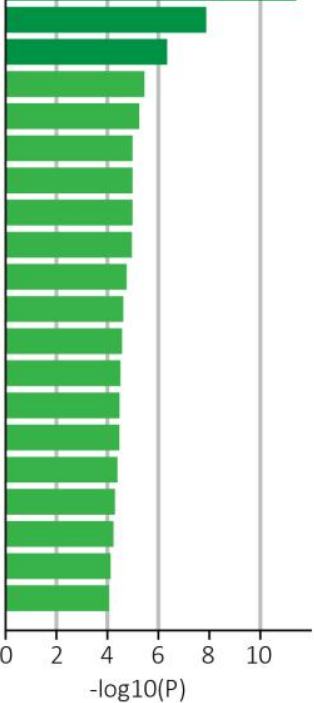

B

Upregulated terms

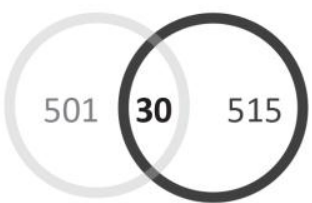

CSDE1 KD in hESC

(Ju Lee et al., 2017)
CSDE1 c.362C>A

patient's fibroblasts
C

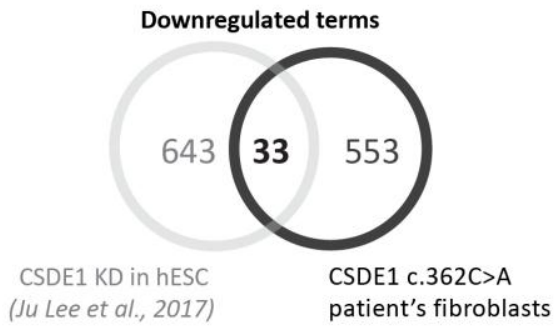

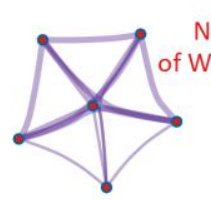

Negative regulation f Wnt signaling pathway $(-5.15)$

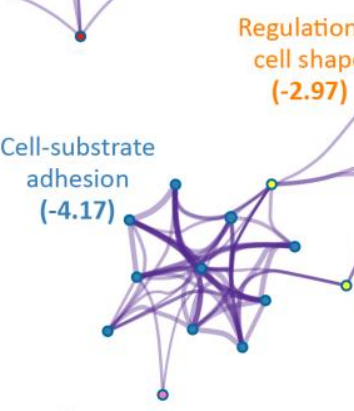

Cell junction organization $(-2.23)$

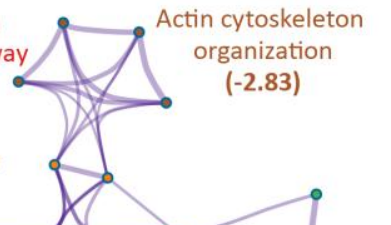

Regulation reproductive process $(-4.46)$

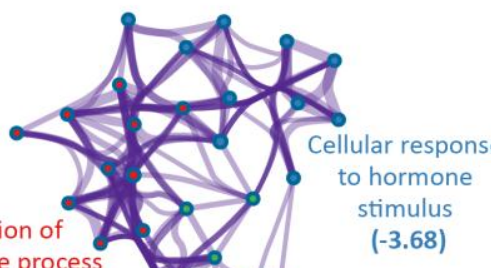

ECM regulators Cellular carbohydrate (-2.50) metabolic process $(-2.27)$
Cell-cell ction assembly (-3.26)

053 downstream pathway (-3.19) 
Figure 3

A

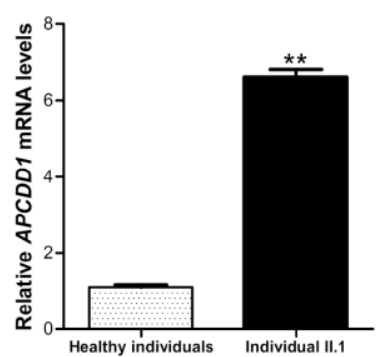

C

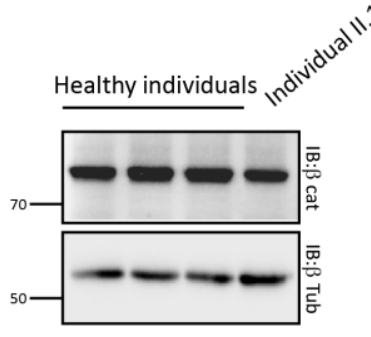

B

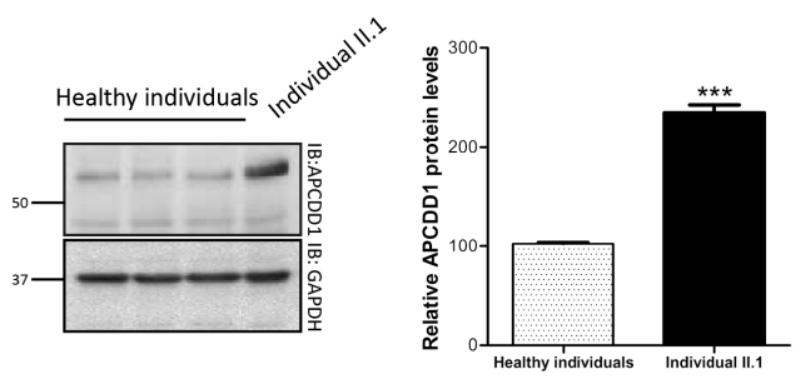

E

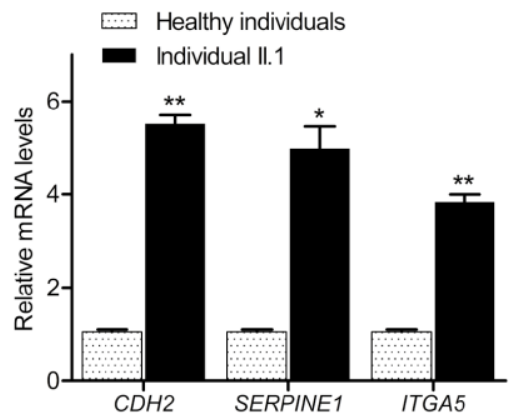

D

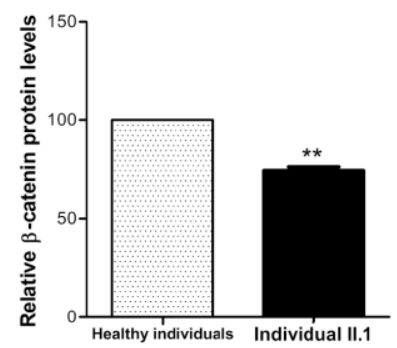

F

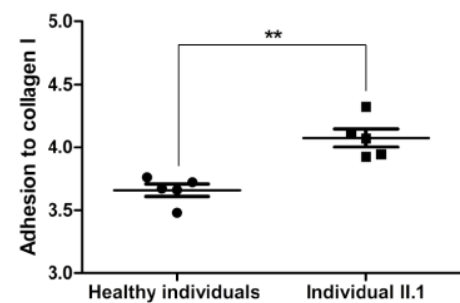




\section{Figure 4}

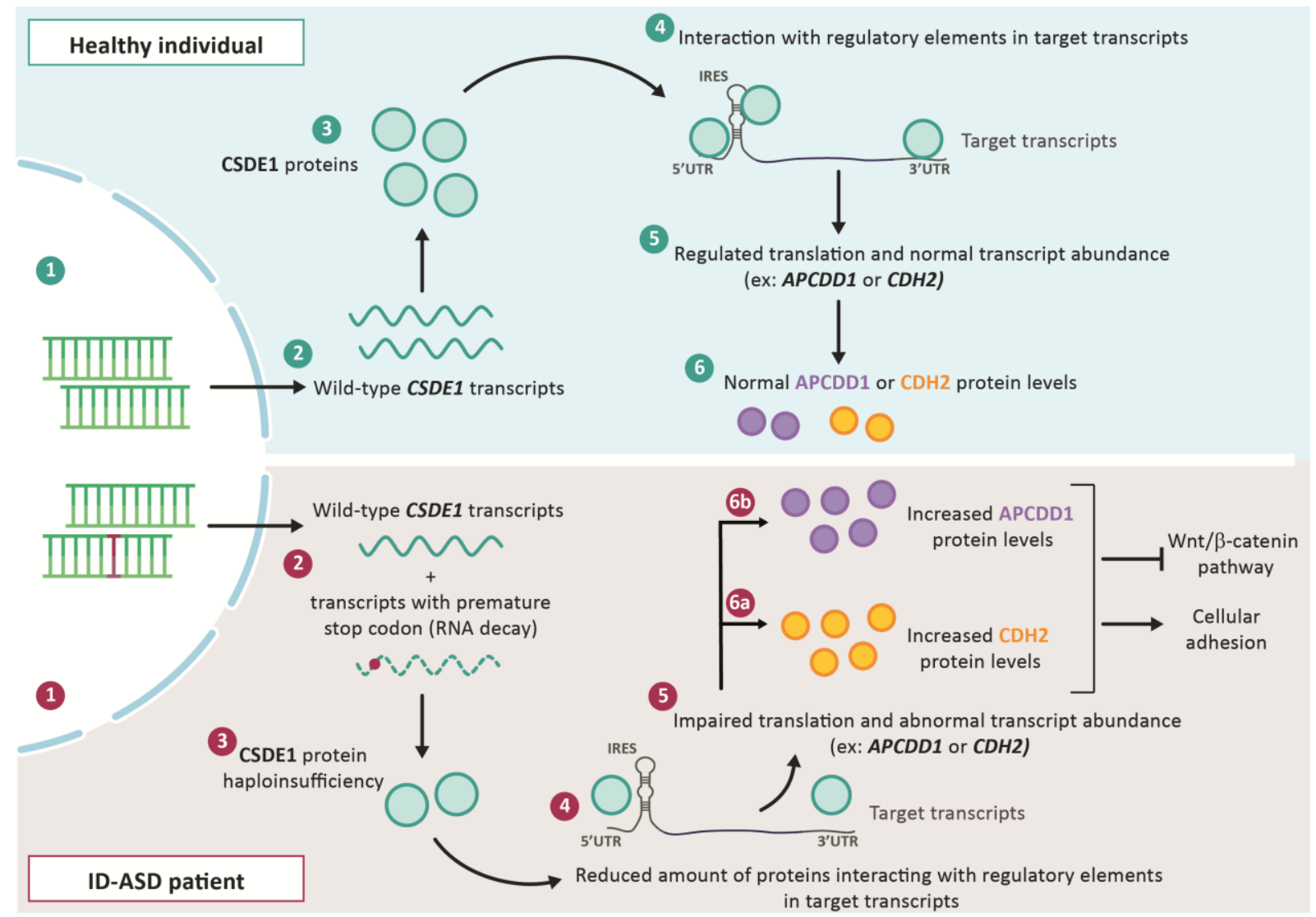




\section{Supplementary Figure 1}
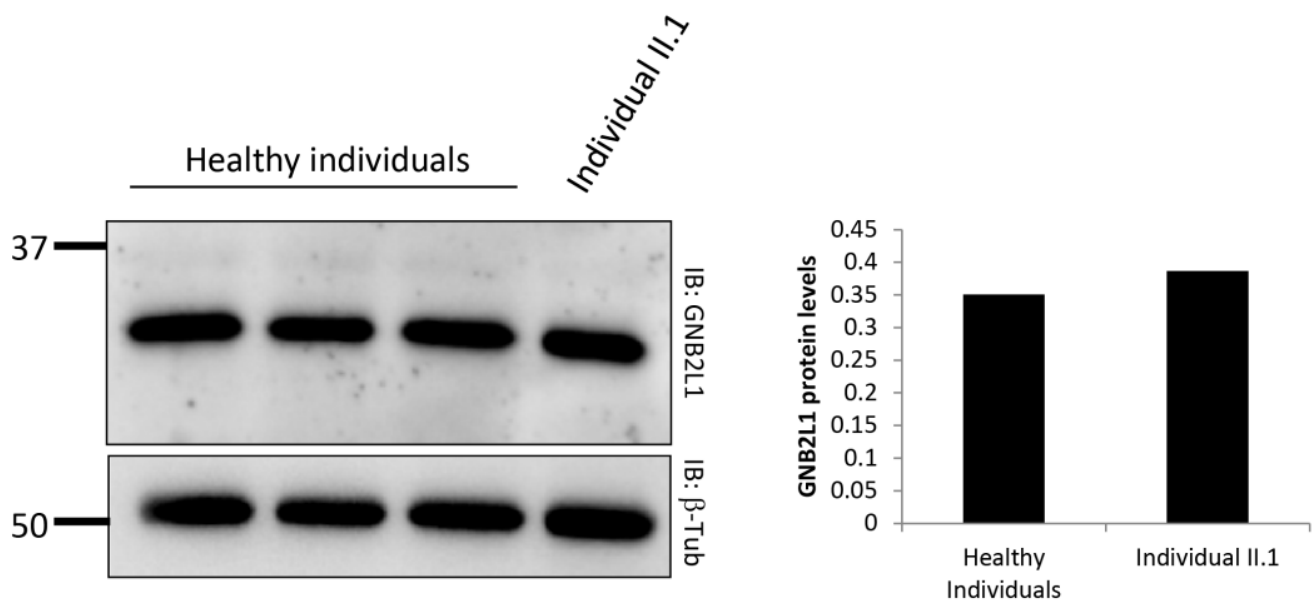

GNB2L1 protein expression in fibroblasts of healthy individuals and individual II.1 Equal amounts of protein extracts from fibroblasts of healthy individuals and individual II.1 were subjected to SDS-PAGE and immunoblotted with GNB2L1 antibody. The GNB2L1 signal was quantified with ImageJ software and normalized to the amount of $\beta$-tubulin used as a loading control. 